\title{
The Learning Effectiveness of the Concept Map Approach of e-Learning Applied to a Math Class of Special Educational Students in a Vocational School
}

\author{
Wan-Ju Chen, Hong-Min Lin, and Shu-Fen Nien
}

\begin{abstract}
In order to improve the learning math capability among learning with disabilities in a special education class at a vocational school, the researchers tried to understand the learning predicament of special education students and tried to apply the Concept Map approach of e-learning to a math class. Also the researchers sought to explore the predicament of action process, solution methods, professional growth and the consequences. The research adopted the execution and observation of action research, interviews of 8 research participants and collected qualitative and quantitative data, evaluated the effect of action research and revised the action research. The results of the findings of this study were first, providing assistance to students by applying the Concept Map approach of teaching material; second, effective learning and positive feedback due to the Concept Map approach of e-learning; third, the use of blended (mixed) e-learning improves apprehension; and, finally, the Concept Map approach of e-learning can be employed on after-class review and remedial work. Based on these findings, the researchers provided concrete suggestions for teaching practices in the future.
\end{abstract}

Index Terms-Action research, concept map approach, disability, e-learning, special educational program of vocational school.

\section{INTRODUCTION}

High-technology has been developing for decades so that using the computer has been popularized in many industries [1], [2]. Recently teaching of e-learning has been applied in classes and to research topics. In general education, network or e-learning has been applied to teaching and learning. E-learning is not restricted by space and time and also can provide individual multi-interaction so it can make up for the inadequacies of teaching activity in the traditional class room[3], [4]. Therefore, through assistive technology, it is not a dream to utilize e-learning for students with disabilities [5].

E-learning has had a serious impact on the learning

Manuscript received September 20, 2013; revised December 16, 2013

Wan-Ju Chen is with the Department of Business Administration, Taiwan Shoufu University. No.168,Nanshih Li, Madou district, Tainan County 72153, Taiwan ROC and is learn at Department of Industrial Education and Technology, National Changhua University of Education No.2, Shi-Da Road, Changhua City 500, Taiwan, R.O.C. (e-mail: post123465@gmail.com).

Hong-Min Lin is with the Department of Special Education, National Taichung University of Education. No.140, Minsheng Rd., West Dist. Taichung City 40306, Taiwan, R.O.C. (e-mail: tcivs2266@yahoo.com.tw).

Shu-Fen Nien is with the Department of Industrial Education and Technology, National Changhua University of Education, No.2, Shi-Da Road, Changhua City 500, Taiwan, R.O.C. (e-mail: f90312004@yahoo.com.tw). environment, teaching material, and the role of teaching.

A lot of scholars aggressively plan to promote e-learning by developing e-learning content suitable and advantageous to the circumstances. The basic elements of curriculum design of e- learning are providing the learning framework and helping learners form overall concepts. However, it will be a challenge for teachers to exploit information technology on teaching material or curriculum design [6].

For disabilities students, the important issue is how to let them employ digitalization equipment and have access to digital information and what digital content is conducive to the needs of the disabilities student so as to improve learning effectiveness. For this line of research, the educators should understand how to select appropriate teaching methods to match different students' needs and to know the learning procedure and cognitive development in e-learning.

Concept Map is a concise teaching tool to guide students to meaningful learning [7]. Concept Map can improve students' ability to analyze and compile important concepts, relationships between concepts, and knowledge structure; it also helps teachers understand students' knowledge structure and the concept of error occurring with students. Applying Concept Map to teaching will help the concept of knowledge domain to be organized into a system. However, Concept Map theory doesn't have much application to the special education field. For this reason, in order to allow learners with disabilities to fully understand the contents of the course of study, the Concept Map showing the overall curriculum framework is suitable.

In short, this study focuses on turning a mathematics trigonometric course into teaching material content by using Concept Maps as a tool to develop a set of e-learning materials for learning disabled students in vocational resource classes.

\section{The Research Purpose}

1) Apply Concept Map to mathematics e-learning material.

2) Examine the Concept Map approach of e-learning for mathematics achievement of learning disability in the special educational program of a vocational school.

3) Address specific suggestions about the Concept Map of e-learning.

\section{LITERATURE REVIEW}

\section{A. E-Learning}

Learners adopt computer and Internet technology to be 
engaged in learning activity. Digitized teaching context by Internet creates the learning experience and carries out the learning model in different times and space. In general, the positive qualities of e-learning are that it is integrated, interactive, user-friendly, non-linear and prompt [8], [9]. The characteristics of e-learning for learners with disability [10] include that first, difficult concepts and theoretical principles can be visualized easier through e-learning, and so facilitate learning; second, operational e-learning materials allow students easier access to participation; third, multimedia learning style, being flexible, aids students' apprehension; fourth, e-learning cannot be restricted by space and time, so students have more opportunity to learn; fifth, the Internet environment makes it more convenient to obtain information; sixth, students like to learn because of the high level of interaction in the e-learning environment. Therefore, the characteristics of e-learning can improve the learning curve of students with disabilities and assist them effectively [10].

\section{B. Concept Map}

Gestalt psychology scholars believe that the human perception of visual images is a form organized by the perceptual system and that it emphasizes the cognitive processes of the organization, and the integrity of behavior and experience. Concept Map is developed into a learning tool to help students develop spatial thinking capability, by Novak and Gowin in 1984 [11]. Concept Map is a concise teaching tool to guide students to meaningful learning [7]. According to experimental research, the Concept Map not only plays an important role in learning theory but also has a positive effect in the learning process [12]-[16].

TABLE I: CHARACTERISTIC DESCRIPTION OF PARTICIPANTS

\begin{tabular}{|c|c|c|}
\hline participant & Gender & Characteristic Description \\
\hline A & male & $\begin{array}{l}\text { 1. Learning situation is acceptable } \\
\text { 2. Mathematical ability is poor } \\
\text { 3. Language ability is acceptable } \\
\text { 4. Ability to memorize is acceptable } \\
\text { 5. Comprehension ability is not good } \\
\text { 6. Inattentive over a long-term. }\end{array}$ \\
\hline $\mathrm{B}$ & male & $\begin{array}{l}\text { 1. Learning speed has been slow, but the parents will supervise and assist him. } \\
\text { Also, prefers one-on-one teaching } \\
\text { 2. Performs well in social studies and natural science. } \\
\text { 3. The ability to memorize and attention span are good. } \\
\text { 4. In math course, the exercise of addition and subtraction, of multiplication and division, can be done by } \\
\text { himself. } \\
\text { 5. Contrary thinking and inference ability is difficult. } \\
\text { 6. In English, mathematics, physics and chemistry, simplification and repetition improve comprehension. }\end{array}$ \\
\hline $\mathrm{C}$ & male & $\begin{array}{l}\text { 1. A passive and slow learner; also, slack and silent in class. } \\
\text { 2. Comprehensive ability is insufficient but likes copying teaching material. } \\
\text { 3. Attention is more decentralized so short concentration span. } \\
\text { 4. Comprehension is regular but ratiocination ability is below par. } \\
\text { 5. The ability to memorize is poor. } \\
\text { 6. Reading comprehension is difficult but mathematical understanding is at average level. } \\
\text { 7. The copying ability is excellent in language art, but little understanding of its meaning. }\end{array}$ \\
\hline $\mathrm{D}$ & male & $\begin{array}{l}\text { 1. Participates in classroom activities. } \\
\text { 2. Generally able to complete homework. } \\
\text { 3. Learning disorders are so great that memorizing, understanding, writing and math is difficult. } \\
\text { 4. Memory, comprehension, inference, attention all poorer than students of the same age. } \\
\text { 5. Often unable to understand basic mathematical theorems or application to the problem-solving. } \\
\text { 6. Reading skills and language abilities are poor, but writing is neat. } \\
\text { 7. Literacy, reading, dictation and math are difficult subjects - slow learning with many mistakes. }\end{array}$ \\
\hline $\mathrm{E}$ & male & $\begin{array}{l}\text { 1. Learning ability and attitude are good but the ability to memorize is poor. } \\
\text { 2. Language art and mathematical ability are weak. } \\
\text { 3. Compared with their peers, memory span is weaker. } \\
\text { 4. Inference ability is acceptable but attention is more decentralized. }\end{array}$ \\
\hline $\mathrm{F}$ & male & $\begin{array}{l}\text { 1. With gentle personality and emotional stability, learning attitude is suitable, but easily distracted and } \\
\text { needs to be prodded. } \\
\text { 2. With imaginative and creative abilities, likes to draw small illustrations and create comics. } \\
\text { 3. The ability to memorize, comprehension ability and inference ability are adequate. } \\
\text { 4. In math class easily distracted, the calculation speed is slow, reading difficulties in mathematics chart. }\end{array}$ \\
\hline G & male & $\begin{array}{l}\text { 1. Self-motivated learner, actively answers the teacher in class, and finishes homework on time. } \\
\text { 2. The ability to memorize is acceptable but inference ability is weak. } \\
\text { 3. The basic four fundamental operations of arithmetic are good but inference ability needs to improve. }\end{array}$ \\
\hline $\mathrm{H}$ & male & $\begin{array}{l}\text { 1. Comprehension ability, attention ability and inference ability are weak. } \\
\text { 2. Reading and writing is slow and often forgets whatever teachers say. } \\
\text { 3. Slow, passive learning, and easily distracted. } \\
\text { 4. Math performance is poor because comprehensive ability is weak. }\end{array}$ \\
\hline
\end{tabular}

Concept Map provides some features for learning, such as hierarchical structure display [17], [18], visualized symbolic knowledge structure [18], leading thinking activity in the learning process [19], effective integration [20], and improving thinking by the composition of a picture [21]. Hence, applying Concept Map to teaching will help the concept of knowledge domain to be organized into a system.
Also, the characteristics of making material into a Concept Map are quite consistent with the principles of special education teaching material compilation.

Concept Map expresses concept by node, which is the appropriate connected language between concepts form the meaningful proposition. Concept Map has two constructional modes: expertise construction and learner self-construction. 
In expertise construction, the learner can effectively understand the main idea and skill structure, can definitely learn interaction between concepts and hierarchy relationship, and can make up for the inadequate literature by acquiring knowledge and skill [22].

Shi [3] demonstrates that the concept map of each chapter content should be applied in the beginning of each chapter for the design of e-learning curriculum to assist learners to understand curriculum framework and summary.

In this research, the Concept Map adopts expertise construction. Teachers transform trigonometric function into the Concept Map mode. Then students learn from e-learning material, designed by compiling this Concept Map.

\section{Action Research}

Action research is going to explore self-analysis in the form of self-examination in the field of teaching practices, to identify concerns, and to check the value of the problem statement. Teachers improve their teaching practices by this process and have a better understanding of their teaching ability, beliefs, and attitudes.

\section{RESEARCH METHODS AND IMPLEMENTATION}

This study focuses on the effect of teaching activities on students. Students use the teaching platform of the computer Internet access, ADDIE, to learn course content. The content of teaching materials based on the ADDIE platform of computer compiles "trigonometry" materials by the Concept Map approach. Moreover, the Chinese version of Moodle1.9.1 online learning platform software is used in this study. In the learning Moodle platform, teachers do not need to have the ability of writing programming web but can design a teaching unit network. Using the Moodle learning platform, teachers can reduce the burden of editing software, so that they can concentrate on the instructional design. The Moodle network learning platform exists for all courses associated with explanatory narrative embedded HTML with the basic functions of showing pictures, hyperlinks, layout settings, and the form.

This study chooses randomly students with learning disabilities within the resource class of a vocational high school as implementation objects of action programs.

Based on the Concept Map approach in developing e-learning materials, it then carries out the program by collecting the data of the action program and explores the impact of the Concept Map approach of "e-learning" on students with learning disabilities in the resource classes of a vocational high school studying mathematics "trigonometric functions" unit.

\section{A. Study Participants}

The study selects randomly eight sophomore students with learning disabilities attending regular classes in the vocational school. The students' details are as follows Table I.

\section{B. Instructional Design}

The course designed for this study using the Concept Map is presented in Table II.

\section{E-Learning Materials Design}

Having analyzed teaching strategy from the literature on the "concept map approach of e-learning" the following materials are included into e-learning: Cartesian Coordinates, Directed Angle, Measurement and Conversion of Angle and Definition of Trigonometric Functions.

The study will proceed for four weeks while researching the "Concept Map approach of e-learning" materials development, as suggested by [23] that developed the step-based Concept Map.

\section{Research Tools}

\begin{tabular}{|c|c|c|}
\hline $\begin{array}{l}\text { Teaching } \\
\text { Unit }\end{array}$ & The Subject & Course Content \\
\hline Unit 1 & $\begin{array}{l}\text { Cartesian } \\
\text { coordinates }\end{array}$ & $\begin{array}{l}\text { Understand line coordinate } \\
\text { Understand Cartesian coordinates }\end{array}$ \\
\hline Unit 2 & Directed angle & $\begin{array}{l}\text { Definition of directed angle } \\
\text { Understand standard position } \\
\text { angle } \\
\text { Understand quadrant angle } \\
\text { Understand conterminal angle }\end{array}$ \\
\hline Unit 3 & $\begin{array}{l}\text { Measurement and } \\
\text { conversion of angle }\end{array}$ & $\begin{array}{l}\text { Understand the meaning of } \\
\text { measure in degree } \\
\text { Understand the meaning of } \\
\text { measure in radian } \\
\text { Understand the conversion of the } \\
\text { measure of angle }\end{array}$ \\
\hline Unit 4 & $\begin{array}{l}\text { Definition of } \\
\text { trigonometric } \\
\text { functions }\end{array}$ & $\begin{array}{l}\text { Understand the definition of } \\
\text { trigonometric functions } \\
\text { Learn about trigonometric values } \\
\text { of } 30,45,60 \text { degrees }\end{array}$ \\
\hline
\end{tabular}

The research tools adopt teaching materials of e-learning and learning achievement scale. The scale has been prepared based on the following main purpose. It is to measure the academic achievement of students in the subjects of "trigonometric functions." According to the proportion of the teaching objectives, teaching content and teaching hours, a teaching unit is shaped to ensure that the sample questions are sufficient to represent for the measurement of areas.

\section{RESEARCH PROGRESS AND ANALYSIS}

In order to improve the learning effectiveness of the mathematics students with learning disabilities, the researchers try to adopt the Concept Map approach of e-learning to make students with disabilities learn trigonometric functions. Furthermore, through action research, the task and the solution in the course of action is being explored.

Before the Concept Map approach teaching is applied, the researchers through observation and interviews seek to record the circumstances of the initial point of the study and also seek to understand students' performance in the trigonometric unit, as shown in Table III.

From the evidence of Table III, most students do not have a good performance in the trigonometric unit, especially on two units-measurement and conversion of angle and trigonometric functions.

Before applying the Concept Map approach of e-leaning, students with disabilities were not familiar with the concept map. After explaining Concept Map approach of teaching, most students agreed that the Concept map approach is easier 
to master.

"I think it is easy to understand this Concept Map "(A01)

"Concept Map" seems relatively simple" (C01)
"It is easy to remember the key point of text' content" (E01)

TABLE III: PRE-TEACHING OBSERVATION AND INTERVIEW BEFORE THE APPLICATION OF THE CONCEPT MAP APPROACH OF E-LEANING IN THE STUDY

\begin{tabular}{|c|c|c|c|c|c|}
\hline student & $\begin{array}{c}\text { Cartesian Coordinates } \\
(20 \%)\end{array}$ & $\begin{array}{l}\text { Directed Angle } \\
\qquad(20 \%)\end{array}$ & $\begin{array}{c}\text { Measurement and } \\
\text { Conversion of Angle }(30 \%)\end{array}$ & $\begin{array}{l}\text { Trigonometric functions } \\
\qquad(30 \%)\end{array}$ & total \\
\hline $\mathrm{A}$ & 5 & 5 & 5 & 5 & 20 \\
\hline B & 10 & 5 & 10 & 10 & 35 \\
\hline $\mathrm{C}$ & 5 & 5 & 5 & 10 & 25 \\
\hline $\mathrm{D}$ & 5 & 8 & 8 & 10 & 31 \\
\hline$E$ & 10 & 12 & 15 & 10 & 47 \\
\hline $\mathrm{F}$ & 8 & 8 & 10 & 10 & 36 \\
\hline $\mathrm{G}$ & 10 & 5 & 5 & 5 & 25 \\
\hline $\mathrm{H}$ & 5 & 8 & 5 & 5 & 23 \\
\hline
\end{tabular}

TABLE IV: THE PERFORMANCE IN THE FIRST STAGE OF THE ACTION PROGRAM

\begin{tabular}{|c|c|c|c|c|c|c|}
\hline students & $\begin{array}{l}\text { Cartesian Coordinates } \\
\text { (pre-test) }\end{array}$ & $\begin{array}{l}\text { Cartesian Coordinates } \\
\text { (post-test) }\end{array}$ & $\begin{array}{l}\text { Progress score } \\
\text { (post-test: } \\
\text { pre-test) }\end{array}$ & $\begin{array}{l}\text { Directed angle } \\
\text { (pre-test) }\end{array}$ & $\begin{array}{l}\text { Directed angle } \\
\text { (pre-test) }\end{array}$ & $\begin{array}{l}\text { Progress score } \\
\text { (post-test: } \\
\text { pre-test) }\end{array}$ \\
\hline $\mathrm{A}$ & 25 & 40 & 15 & 25 & 50 & 15 \\
\hline B & 40 & 65 & 25 & 25 & 50 & 25 \\
\hline $\mathrm{C}$ & 25 & 50 & 25 & 25 & 40 & 15 \\
\hline$E$ & 50 & 65 & 15 & 60 & 75 & 15 \\
\hline $\mathrm{F}$ & 40 & 50 & 10 & 40 & 50 & 10 \\
\hline $\mathrm{G}$ & 50 & 50 & 0 & 25 & 50 & 25 \\
\hline $\mathrm{H}$ & 25 & 40 & 15 & 40 & 50 & 10 \\
\hline Average & 35 & 50 & 15 & 35 & 54 & 19 \\
\hline
\end{tabular}

\section{A. The First Phase of the Action Program from the First} Week to the Second Week

\section{1) The effectiveness of teaching}

Pre-test and post-test results on two subject areas, Cartesian coordinates and Directed angle, with application of Concept Map approach of e-learning being shown in Table IV.

\section{2) Teacher-student dialogue}

After collecting the comments from students and teachers in the resource class of this study, the following information has emerged: the research objects agree that e-learning is a good method of learning and to finding out the key point of the subject content being studied.

"I feel a sense of achievement when I use the computer at the first time" (A02)

"Using this approach makes it easier for me to learn" (B02)

"When the teacher draws up a Concept Map, this makes it easier to understand" (C02)
"Using the Concept Map makes it easier to learn" (E02)

3) Revision and respondence of study

In the first stage of the research process, the researchers conduct a number of revisions. That is because the application of Concept Map Approach of e-learning shows not much progress; moreover, the use of computerized evaluation cannot analyze the student's problem; third, not providing the problem-solving process to the students makes them incapable of working out the questions given in an exam.

\section{B. The Second Phase of the Action Program from the} Third Week to the Fourth Week

\section{1) The effectiveness of teaching}

On this second phase, the research objects are divided into two groups. One is still applying the concept map approach of e-learning; another group implements a traditional teaching first, and then uses the concept map approach of e-learning.

TABLE V: The Performance In the Second Phase of the Action PRogram

\begin{tabular}{|c|c|c|c|c|c|c|c|}
\hline stud & & \multirow{2}{*}{$\begin{array}{c}\begin{array}{c}\text { Unit conversion } \\
\text { (pre-test) }\end{array} \\
16\end{array}$} & \multirow{2}{*}{$\begin{array}{c}\begin{array}{c}\text { Unit conversion } \\
\text { (post-test) }\end{array} \\
50\end{array}$} & \multirow{2}{*}{$\begin{array}{c}\text { Progress } \\
\text { score } \\
\text { (post-test: } \\
\text { pre-test) } \\
34 \\
\end{array}$} & \multirow{2}{*}{$\begin{array}{c}\begin{array}{c}\text { trigonometric } \\
\text { functions } \\
\text { (pre-test) }\end{array} \\
16 \\
\end{array}$} & \multirow{2}{*}{$\begin{array}{c}\text { trigonometric } \\
\text { functions } \\
\text { (post-test) }\end{array}$} & \multirow{2}{*}{$\begin{array}{c}\begin{array}{c}\text { Progress } \\
\text { score } \\
\text { (post-test: } \\
\text { pre-test) }\end{array} \\
44 \\
\end{array}$} \\
\hline & $\mathrm{A}$ & & & & & & \\
\hline Teaching+ & $\mathrm{G}$ & 16 & 60 & 44 & 16 & 60 & 44 \\
\hline e-learning & $\mathrm{D}$ & 27 & 75 & 48 & 33 & 75 & 42 \\
\hline & $E$ & 50 & 83 & 33 & 33 & 83 & 50 \\
\hline \multicolumn{2}{|c|}{ average } & 27.3 & 67 & 39.7 & 24.5 & 69.5 & 45 \\
\hline \multirow{4}{*}{ e-learning } & $\mathrm{H}$ & 16 & 33 & 17 & 16 & 33 & 17 \\
\hline & $\mathrm{C}$ & 16 & 50 & 34 & 33 & 50 & 17 \\
\hline & $\mathrm{B}$ & 33 & 60 & 27 & 33 & 50 & 17 \\
\hline & $\mathrm{F}$ & 33 & 50 & 17 & 33 & 60 & 27 \\
\hline \multicolumn{2}{|c|}{ average } & 24.5 & 48.3 & 23.7 & 28.7 & 48.3 & 19.5 \\
\hline
\end{tabular}


Unit conversion and trigonometric functions utilized in e-learning and teaching with e-learning are shown in Table $\mathrm{V}$.

From Table V, there is progress in both the e-learning group and teaching plus e-learning group. Also, the research finds that applying the teaching plus e-learning method results in more progress than applying only the e-learning method.

\section{2) Teacher-student dialogue}

The students express how the use of Concept Maps helps them remember. Also, using computer platform allows them to repeat learning on their own-time and get explanations for unknown questions in exams or homework.

"After several weeks, I like using teaching platform."(H02)

"Using the Concept Map makes it easier to learn." (B02)

"With the hard questions given in an exam, I can see a detailed explanation." (A02)

"I can see the problem-solving of the exercises in teaching platform." (G02)

"Conceptual Map can be easy to remember." (D02)

"This is a good way to remember." (E02)

\section{3) Revision and respondence of study}

The results from Table $\mathrm{V}$ show that before using Concept Map of e-learning, it will be more effective to pre-teach students and correct the assessment system first; then combine the appropriate assessment. After implementing the teaching method involved into this research, the interesting results from the disabled students are as follows. First, it is easy to learn on the teaching platform; second, the Concept Map approach of e- learning provides a good way to learn; third, students with the learning activities of the Concept Map approach of e-learning have a positive attitude; fourth, a small portion of students have difficulty in using the teaching platform.

\section{CONCLUSIONS AND RECOMMENDATIONS}

\section{A. Conclusions}

The study illustrates that using the Concept Maps-designed learning materials is a great help for students. Moreover, using hybrid e-learning leads to better learning results; also, students thru e-learning teaching methods of the Concept Map can effectively learn to acquire knowledge, skills, and show a good attitude towards learning. In short, the e-learning of Concept Map approach for students with disabilities shows positive learning results. However, the difficulty of this research paper is that to compose the suitable e-learning material for the testing students. To create suitable e-learning materials there needs to be cooperation among the special-education professional, the math expert and the e-media design expert.

\section{B. Recommendations for Further Research}

The results of the study point to recommendations for further research. First, it is worthwhile to promote the e-learning of Concept Map approach for students of special needs. Second, encourage all students to use the learning platform. Third, schools should provide more support and assistance for students' study. Fourth, the e-learning of Concept Map approach can be used in remedial teaching and after-school review. Fifth, e-learning research should continue throughout the educational industry. Finally, future research should be longitudinal research so that a complete experimental record will allow a better understanding of students' learning behavior and mental processes and also prove the reliability of the paper.

\section{REFERENCES}

[1] Y. A. Yang and P. Wang, "Learning on Web-Based Constructive Mathematics Learning System for Children with Disability," Grants Special study of National Science Council, 2001.

[2] M. L. Yeh, H. H. Chen, and C. H. Chang, "Developing a computer-assisted instruction CD-ROM program for nursing," Formosan Journal Medicine, vol. 6, no. 6, pp. 944-950, 2002.

[3] W. L. Shi, "Digital teaching strategies based on learning theory," Living Technology Education, vol. 40, no. 2, pp. 32-41, 2008.

[4] C. L. Hsu, "The Study of Computer Assisted Instruction and E-learning in Instructional Design Perspective in the Future," Educational Resources and Research, vol. 78, pp. 21-40, 2007.

[5] W. C. Tseng, "Analyzing web accessibility of Chinese online learning web sites," Journal of National Taipei Teachers College Education, vol. 17, no. 1, pp. 271-298, 2004.

[6] M. J. Rosenberg, E-Learning strategies for delivering knowledge in the digital age, New York: McGraw-Hill Companies Inc., 2001.

[7] C. Akinsanya and M. Williams, "Concept mapping for meaningful learning,” Nurse Education Today, vol. 24, no. 1, pp. 41-46, Jan. 2004.

[8] B. Li. (2004). The Application of Multimedia in Teaching. [Online]. Available: http://www.fhjh.tp.edu.tw/erc/

[9] B. Khan, Web-based instruction, Englewood Cliffs, New Jersey: Education Technology Publications, 1997.

[10] M. T. Chen, "The turning point, challenger and coping of the disable students in e-learning environment," Special Education Matters for Teaching Coupus, pp. 129-151, 2003.

[11] Y. Y. Li, "Cognitive teaching theory and strategy," Taipei: Psychology, 2000.

[12] T. S. Lin, "The Effect of Teaching with Concept Mapping with Different Introductive Procedure on Elementary Scientific Concept Learning," Kaohsiung Normal University Journal, vol. 19, pp. 105-122, 2006.

[13] L. C. Lin, H. K. Ko, and S. Y. Lin, "Comparing the Differences of Students' Attitude toward Concept Mapping after an Intervention in a Nursing Baccalaureate Program," Chang Gung Nursing, vol. 20, no. 4, pp. 441-449, 2009

[14] C. C. Chiou, "Applying Concept Mapping Learning Strategy to Business Accounting: Collaborative or Individual," Kaohsiung Normal University Journal, vol. 21, pp. 87-104, 2006.

[15] X.C. Zheng, "Concept mapping teaching methods used in the design of teaching activities of the Elementary School Transport Technology simple hand-launch machine production," Living Technology Education, vol. 39, no. 7, pp. 25-35, 2006.

[16] M. Ahlberg, P. Aanismaa, and P. Dillon, "Education for sustainable living: Integrating theory, practice, design, and development," Scandinavian Journal of Educational Research, vol. 4, no. 2, pp. 167-185, 2005.

[17] C. C. Huang, "Concept mapping training in reading instruction on the application," Jiao shi zhi you, vol. 42, no. 1, pp. 29-36, 2001.

[18] C. G. Williams, "Using concept maps to assess conceptual knowledge of function," Journal of research in mathematics education, vol. 29, no. 4, pp. 414-422, 1998.

[19] M. N. Yu, Meaningful learning - Concept Mapping Study, Taipei: Shang Ding, 2003.

[20] H. J. Chen and J. S. Horng, "Nine-year comprehensive activities implemented concept mapping study on the effectiveness of teaching," Journal of Home Economics Education, vol. 7, pp. 1-29, 2005.

[21] C. C. Wang, "Expert and Novice Differences in Problem Solving and the Implication to Instruction," Educational Research \& Information, vol. 5, no. 2, pp. 80-90, 1997.

[22] R. S. Shaw and M. G. Shu, "A Study of Applying Knowledge Maps to Instructional Material Design of E-learning," Journal of Information Management, vol. 16, no. 1, pp. 163-180, 2008.

[23] H. P. Yueh and Y. T. Teng, "Exploring Applications of Knowledge Map as Strategies for Instruction and Learning," Secondary Education, vol. 60, no. 2, pp. 128-140, 2009. 


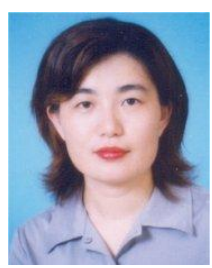

Wan-Ju Chen was born on April 5, 1967, Taiwan. She is the Ph.D candidate of Department of Industrial Education and Technology at National Changhua University of Education in Changhua city, Taiwan, R.O.C. She is a lecturer in business administration Department at Taiwan Shoufu University, Taiwan. She has published in ICIC Express Letters, An International Journal of Research and Surveys. Her research interests include intellectual capital, knowledge management, human research management, e-learning and education.

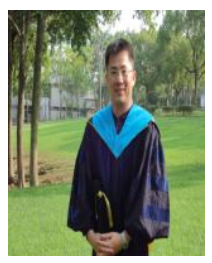

Hong-Min Lin was born on May 8, 1973, Taiwan. He is the Ph.D of Department of Industrial Education and Technology at National Changhua University of Education in Changhua city, Taiwan, R.O.C. He is a teacher at Taichung Industrial Vocation School and part-time associate professor in the department of special education at National Taichung University of Education, Taiwan. He has published in ICIC Express Letters, An International Journal of Research and Surveys. His research interests include instruction of special education, e-learning and career education.

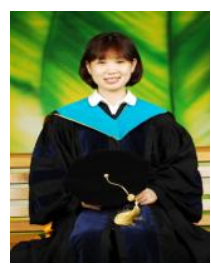

Shu-Fen Nien was born on Jan. 7, 1975, Taiwan. She is the $\mathrm{Ph}$. D candidate of Department of Industria Education and Technology at National Changhua University of Education in Changhua city, Taiwan, R.O.C. She is a teacher at National Beidou Senior Home Economic and Commercial Vocation High School in Taiwan. She has published in ICIC Express Letters, An International Journal of Research and Surveys. He research interests include principal's leadership, e-learning, positive psychological capital and education. 